\section{TRENDS IN INTERNATIONAL ARMS TRANSFERS, 2010}

\author{
PAUL HOLTOM, LUCIE BÉRAUD-SUDREAU, MARK BROMLEY, \\ PIETER D. WEZEMAN AND SIEMON T. WEZEMAN
}

\section{INTRODUCTION}

The SIPRI Arms Transfers Database contains information on all international transfers of major conventional weapons (including sales, gifts and transfers of technology) to states, international organizations and armed non-state groups; the database does not cover international transfers of small arms. The database can be used to (a) monitor trends in the volume of transfers of major conventional weapons and (b) identify the quantity and types of weapons that have been transferred, broken down by supplier or recipient. This information can be used to answer such questions as:

- Who are the main suppliers and recipients of major conventional weapons?

- How have the relationships between different suppliers and recipients changed over time?

-Where do countries in conflict get their weapons?

- How do states implement their export control regulations?

- Where are potentially destabilizing build-ups of weapons occurring today?

The SIPRI Arms Transfers Database is available online at $<\mathrm{http} / / \mathrm{www}$. sipri.org/databases/armstransfers $>$. From 14 March 2011 it includes newly released information on arms transfers during 2010. This Fact Sheet describes the trends in international arms transfers that are revealed by the new data. It lists the main suppliers and recipients for the period 2006-10 and describes the changes in regional trends.

Since the volume of deliveries of arms can fluctuate significantly from one year to the next, SIPRI uses a 5-year moving average to give a more stable measure of the trends in transfers. The volume of international transfers of major conventional weapons in the period 2006-10 was 24 per cent higher than in 2001-2005. The trend for the decade 2001-10 is shown in figure 1.

\section{THE FIVE MAIN SUPPLIERS OF MAJOR CONVENTIONAL WEAPONS, 2006-10}

The five biggest suppliers of major conventional weapons in 2006-10 were the United States, Russia, Germany, France and the United Kingdom (see figure 2 and table 1). The USA and Russia remained by far the largest exporters, accounting for 30 per cent and 23 per cent of all exports,

\section{KEY FACTS}

- The volume of international transfers of major conventional weapons for the period 2006-10 was 24 per cent higher than for the period 2001-2005.

- The five biggest suppliers in 2006-10 were the United States, Russia, Germany, France and the United Kingdom.

- The top five suppliers accounted for 75 per cent of all exports of major conventional weapons in 2006-10, compared with 80 per cent in 2001-2005.

- The five biggest recipients in 2006-10 were India, China, South Korea, Pakistan and Greece.

- The overall share of the volume of international arms transfers accounted for by the top five recipients dropped from 39 per cent in 2001-2005 to 30 per cent in 2006-10.

- States in Asia and Oceania received 43 per cent of all imports of major conventional weapons in 2006-10, followed by Europe (21 per cent), the Middle East (17 per cent), the Americas (12 per cent) and Africa (7 per cent). 


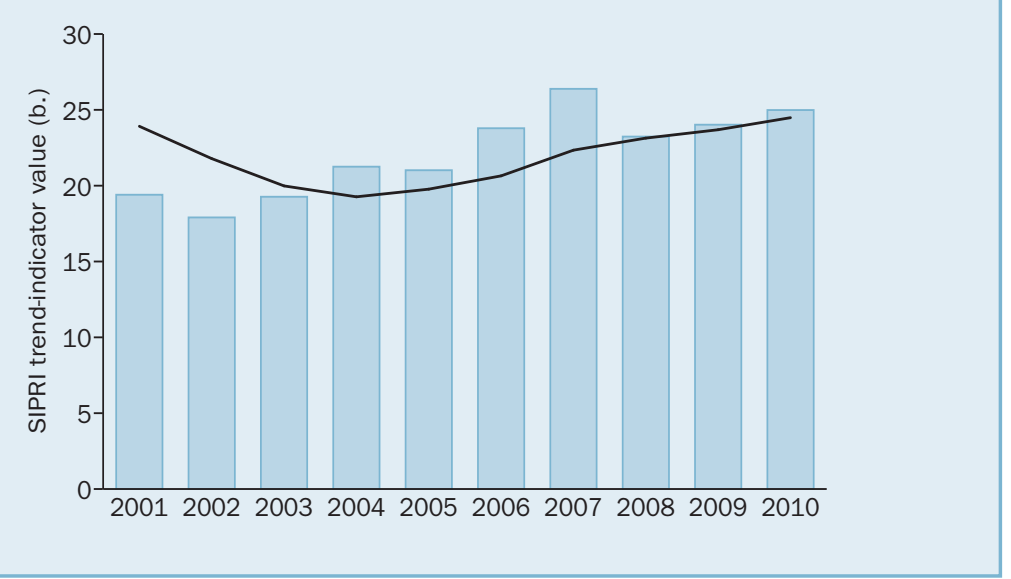

Figure 1. The trend in transfers of major conventional weapons, 2001-10

Note: The bar graph shows annual totals, and the line graph shows the 5 -year moving average. Each data point in the line graph represents an average for the preceding 5 -year period. The SIPRI trend-indicator value (TIV) gives an indicator for the volume of international transfers of major conventional weapons. The method used to calculate the SIPRI TIV is described on the SIPRI Arms Transfers Programme website at <http://www.sipri.org/research/armaments/transfers/measuring>.

Source: SIPRI Arms Transfers Database, as of 14 Feb. 2011, <http://www.sipri.org/ databases/armstransfers>. respectively. The top five suppliers accounted for 75 per cent of all exports of major conventional weapons in 2006-10, compared with 80 per cent in 2001-2005.

\section{The United States}

The USA delivered weapons to 75 recipients in 2006-10, more than any other supplier. Asia and Oceania was the biggest recipient region of US weapons-accounting for 44 per cent of US deliveries, including 22 per cent in total for South Korea, Japan and Taiwan. The Middle East accounted for 28 per cent and Europe for 19 per cent. Among the USA's deliveries in 2010 were 52 combat aircraft, 2439 armoured vehicles and 108 tanks. Nearly all armoured vehicles went to US allies for use in Afghanistan and Iraq. In recent years US decisions to provide more advanced weapons systems to allies have been justified on the grounds that this will enable these states to more effectively meet their own security needs and in turn reduce the number of US troops stationed overseas.

\section{Russia}

Russia exported around 67 per cent of its arms to Asia in 2006-10 and 14 per cent to Africa. India was the largest recipient of Russian arms exports and in 2010 gave its strongest signal to date of continued interest in joint production with Russia of transport and advanced combat aircraft. Despite Russia's concerns with China's copying of its weapon technology and the potential competition on the international arms market, Russia is willing to provide China with S-400 air defence systems, Il-476 transport aircraft and Su-33 carrier-borne combat aircraft for the right price. In 2010 Russia announced that it would not supply five S-300 air defence systems to Iran. It still has outstanding orders for S-300 systems for Algeria, Libya, Kazakhstan and Venezuela. Armenia revealed in 2010 that it was in possession of at least two S-300 systems supplied by Russia.

\section{Germany}

The volume of Germany's arms exports increased by over 96 per cent between the periods 2001-2005 and 2006-10, and its share of the global market rose from 7 per cent to 11 per cent. Ships accounted for 44 per cent of German arms exports in the period 2006-10, and many of the transfers involved licensed production agreements with the recipient states. For example, German deliveries in 2006-10 included four MEKO-A200 frigates 


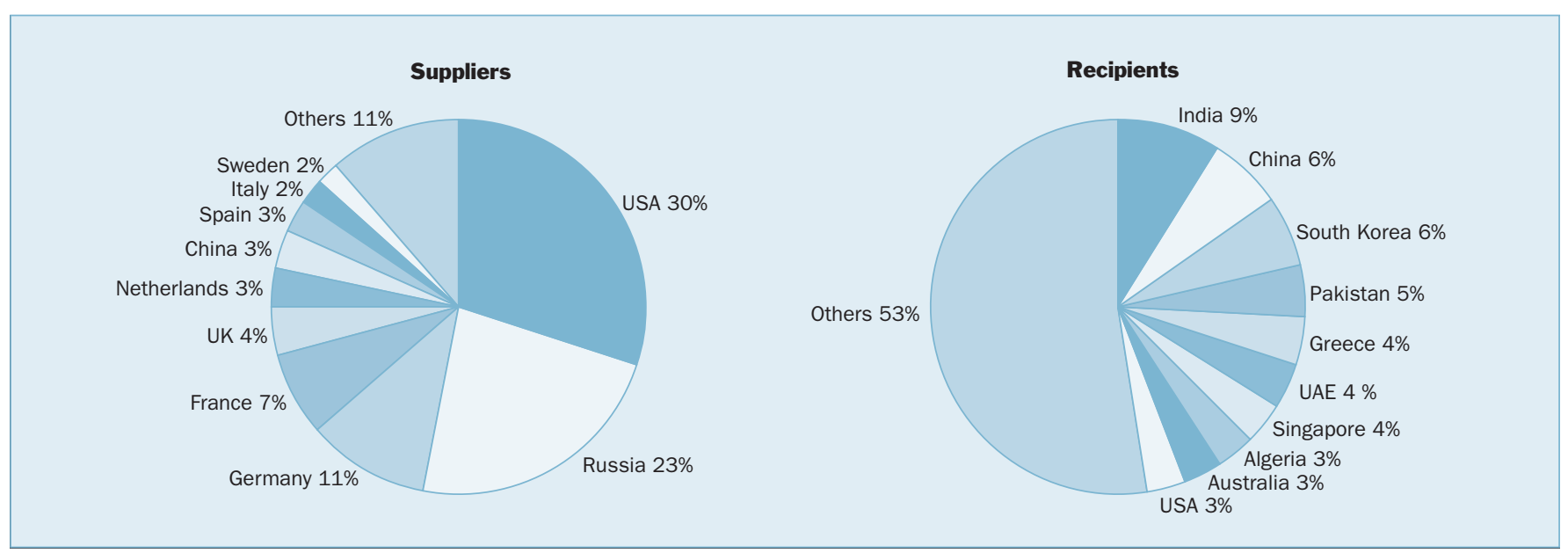

Figure 2. The suppliers and recipients of major conventional weapons, 2006-10

to South Africa, six MEKO-A100 frigates to Malaysia, three Type-214 submarines to South Korea and two Type-209 submarines to Turkey.

\section{France}

The volume of France's arms exports increased by almost 10 per cent between the periods 2001-2005 and 2006-10; however, the share of French arms exports in the global arms trade decreased from 8 per cent to 7 per cent. Aircraft and ships each accounted for one third of French arms deliveries. France has outstanding orders for 11 submarines-6 Scorpene for India and 4 Scorpene and 1 nuclear-powered submarine (SNBR) for Brazil. France again failed to secure an export deal for its Rafale combat aircraft despite intensive lobbying efforts by the French Government for orders in Brazil, India and the United Arab Emirates (UAE).

\section{The United Kingdom}

The volume of British arms exports decreased by 11 per cent between the periods 2001-2005 and 2006-10. In 2006-10, aircraft accounted for 50 per cent of British arms exports. Deliveries included the first 16 of 72 Eurofighter Typhoon to Saudi Arabia and the first 36 of 66 Hawk-100 trainer aircraft to India. Only 16 of the Hawks were directly delivered from the UK, while 8 were assembled in India and 12 were built under licence there. Additionally, the UK continued the supply to the USA M-777 155-mm towed guns for use in Afghanistan. The newly elected British Government pledged to provide increased support for British arms exports in 2010. In August India signed a $\$ 1.1$ billion order for a further 57 Hawk-100 trainer aircraft.

\section{THE RECIPIENTS OF MAJOR CONVENTIONAL WEAPONS,} 2006-10

Since 1950 the states that receive the most major conventional weapons have changed much more than the states that supply the most. However, in recent years, the composition of the five largest recipients has remained relatively stable. In the period 2006-10 their share of the volume of international arms 
Table 1. The top 5 suppliers of major conventional weapons and their largest recipients, 2006-10

\begin{tabular}{|c|c|c|c|c|}
\hline \multirow[b]{2}{*}{ Supplier } & \multirow{2}{*}{$\begin{array}{l}\text { Share of } \\
\text { global arms } \\
\text { exports (\%) }\end{array}$} & \multicolumn{3}{|c|}{ Main recipients (share of supplier's transfers) } \\
\hline & & 1 st & 2nd & $3 \mathrm{rd}$ \\
\hline United States & 30 & South Korea (14\%) & Australia (9\%) & United Arab Emirates (8\%) \\
\hline Russia & 23 & India (33\%) & China (23\%) & Algeria (13\%) \\
\hline Germany & 11 & Greece (15\%) & South Africa (11\%) & Turkey (10\%) \\
\hline France & 7 & Singapore (23\%) & United Arab Emirates (16\%) & Greece (12\%) \\
\hline United Kingdom & 4 & United States (23\%) & Saudi Arabia (19\%) & India (13\%) \\
\hline
\end{tabular}

transfers dropped from 39 per cent $2001-2005$ to 30 per cent (see figure 2 and table 2).

The regional breakdown of arms deliveries has also remained relatively stable. In 2006-10 Asia and Oceania accounted for 43 per cent of imports of major conventional weapons, Europe for 21 per cent, the Middle East for 17 per cent, the Americas for 12 per cent and Africa for 7 per cent.

\section{Africa}

African states' share of international imports of major conventional weapons increased from 5 per cent in 2001-2005 to 7 per cent in 2006-10. In 2006-10, Algeria and South Africa were the two largest arms importers in Africa, accounting for 48 per cent and 27 per cent, respectively, of the region's imports. The third largest recipient of major conventional weapons was Sudan, which accounted for 4 per cent of Africa's imports. In several cases the supply of relatively small volumes of arms to African countries may have had a major impact on regional conflict dynamics.

- Supplies of major conventional arms to Libya were very low in the period between the lifting of the United Nations arms embargo on the country in September 2003 and the imposition of a new UN arms embargo in February 2011. However, France, Italy, Russia and the UK have been competing for expected orders from Libya for combat aircraft, tanks, air defence systems and other weapons. Russia has orders from Libya for six Yak-130 trainer/combat aircraft and two Tarantul Fast Attack Craft, but did not secure an anticipated contract for export of its new Su-35 combat aircraft by the end of 2010 .

- New information became available in 2010 regarding deliveries of major arms to several areas of tension and conflict in sub-Saharan Africa that took place in 2009-10.

- Uganda received 23 T-55AM tanks from Russia and 21 artillery pieces from Israel in 2009.

- Sudan used some of the $14 \mathrm{Su}-25$ combat aircraft delivered by Belarus in 2009 in Darfur, in violation of UN sanctions. In 2010 it became known that the Government of Southern Sudan had ordered 10 transport helicopters for its air force and had received between 77 and 110 T-72 tanks from Ukraine via Kenya in the period 2007-2009.

- In 2010 the Democratic Republic of the Congo received 20 T-72 tanks from Ukraine, and Nigeria received 15 F-7 combat aircraft from China. 
Table 2. The top 5 recipients of major conventional weapons and their largest suppliers, 2006-10

\begin{tabular}{lllll}
\hline & $\begin{array}{l}\text { Share of } \\
\text { global arms } \\
\text { Recipient }\end{array}$ & \multicolumn{2}{l}{ Main suppliers (share of recipient's transfers) } & 3rd \\
\cline { 3 - 5 } imports (\%) & 1st & Russia (82\%) & 2nd & Israel (3\%) \\
India & 9 & Russia (84\%) & France (5\%) & Switzerland (3\%) \\
Shina & 6 & United States (71\%) & Germany (16\%) & France (9\%) \\
Pakistan & 6 & United States (39\%) & China (38\%) & Sweden (6\%) \\
Greece & 5 & Germany (39\%) & United States (29\%) & France (21\%) \\
\hline
\end{tabular}

- In the period 2006-10 Germany accounted for 35 per cent of supplies of major arms to sub-Saharan Africa, China for 10 per cent, Sweden for 10 per cent and Ukraine for 8 per cent. All German and Swedish supplies to the region went to South Africa. China supplied major arms to 16 countries in the region and Ukraine to 8 countries.

\section{The Americas}

States in the Americas accounted for 12 per cent of imports of major conventional weapons in the period 2006-10, compared with 9 per cent in 2001-2005. The USA was the largest importer of conventional weapons in the Americas in 2006-10 and the 10th largest in the world. Chile was the largest importer of conventional weapons in South America in 2006-10 and the 12th largest in the world.

- South America's share of world arms imports increased from 1.5 per cent to 4 per cent, and the total volume of transfers to the region increased by nearly 150 per cent. These figures reflect the significant upswing in both military spending and arms acquisitions in the region in recent years.

- Several states in South America continue to engage in significant force modernization programmes, feeding a sharp upturn in their arms imports. Chile's arms imports increased by 67 per cent between the periods 2001-2005 and 2006-10 while Venezuela's arms imports increased by 359 per cent. Venezuela's arms imports are likely to remain high in the coming years. There are reports that deliveries of T-72 tanks, BMP-3 and BTR- 80 armoured vehicles, and S-300 air defence systems from Russia will begin in 2011.

- Other states in South America, including Argentina, Colombia and Peru, are also engaged in more modest arms acquisition efforts. Ecuador's arms imports increased by 366 per cent between the periods 2001-2005 and 2006-10, although the overall volume of its imports was less than a fifth of either Chile's or Venezuela's. Significant transfers to Ecuador in 2006-10 included 2 Leander frigates from Chile, 16 of a total order of 18 EMB-314 trainer/combat aircraft from Brazil and 6 Mirage-50 combat aircraft donated by Venezuela.

- Orders for Brazilian arms imports increased by 436 per cent between the periods 2001-2005 and 2006-10, driven in large part by licensed production deals with France for 4 Scorpene submarines, 1 SNBR and 50 EC-725 helicopters. However, newly elected Brazilian President Dilma Rouseff has delayed awarding a $\$ 2$ billion contract for advanced 
combat aircraft and a $\$ 6$ billion contract for frigates and offshore patrol vessels (OPVs).

\section{Asia and Oceania}

The volume of deliveries of major conventional weapons to states in Asia and Oceania was 17 per cent higher in the period 2006-10 than in 2001-2005. However, this increase was lower than the global increase of 24 per cent, and Asia and Oceania's share of the global volume fell to 43 per cent in 2006-10 from 45 per cent in 2001-2005. Six of the 10 largest importers in 2006-10 are from the region: India (1st), China (2nd), South Korea (3rd), Pakistan (4th), Singapore (7th) and Australia (9th).

- India was the world's largest importer of major conventional weapons in 2006-10. Its volume of deliveries in 2006-10 was 21 per cent higher than in 2001-2005. Aircraft accounted for 71 per cent of its imports, with deliveries in 2010 of $35 \mathrm{Su}-30 \mathrm{MKI}$ and $10 \mathrm{MiG}-29 \mathrm{SMT}$ combat aircraft from Russia as well as a second Phalcon airborne early warning (AEW) aircraft from Israel.

- Arms transfers to Pakistan increased by 128 per cent between the periods 2001-2005 and 2006-10. Aircraft accounted for 45 per cent of imports, with deliveries to Pakistan in 2010 including $18 \mathrm{~F}-16 \mathrm{C}$ combat aircraft from the USA, $15 \mathrm{JF}-17$ combat aircraft from China and 3 Erieye AEW aircraft from Sweden. Pakistan also received large numbers of airto-air missiles and guided bombs from China and the USA, and antiradar missiles from Brazil.

- While China was the second largest importer of major weapons in 2006-10, deliveries to China in that period were barely half of the volume in 2001-2005. Deliveries in 2010 were limited to helicopters and artillery produced under licence and engines for aircraft, ships and armoured vehicles.

- Deliveries in 2010 to South East Asia were lower than in 2009 but remained higher than in any other year in the period 2001-10. The volume in 2006-10 was 139 per cent higher than in 2001-2005. Viet Nam received 1 Gepard-3 frigate, 1 Bastion coast defence system with Yakhont missiles and $4 \mathrm{Su}-30 \mathrm{MK} 2$ combat aircraft from Russia. It also ordered another $12 \mathrm{Su}-30 \mathrm{MK} 2$ combat aircraft from Russia.

- Australia entered the list of top 10 importers, becoming the 9th largest importer in 2006-10, accounting for 3 per cent of total transfers. Australian imports in 2006-10 increased 66 per cent compared to 20012005. Deliveries included $15 \mathrm{~F} / \mathrm{A}-18 \mathrm{E}$ combat aircraft and the last 2 of 4 AEW aircraft from the USA.

\section{Europe}

European states received 21 per cent of international transfers of major conventional weapons in the period 2006-10, compared with 20 per cent in 2001-2005. Member states of the European Union (EU) accounted for 17 per cent of global arms imports in 2006-10. The largest importer of major conventional weapons in Europe in recent years has been Greece, but the UK and Poland were also among the 20 largest importers in the world in 2006-10. 
- Greece remained among the top five largest recipients of major conventional weapons in 2006-10. During 2010 Greece announced a review of its procurement plans in light of the economic crisis. One of the signs of this change was the decision to postpone a deal with Russia for 415 BMP-3 armoured vehicles. However, in 2010 Greece placed an order for the licensed production of two more Type-214 submarines from Germany, in addition to the four that were ordered in 2000 and 2002. In 2010 Greece took delivery of its first licence-produced Type-214 submarine.

- A number of European states are acquiring major conventional weapons for use in Afghanistan. The UK, which was the 17th largest importer of major conventional weapons in 2006-10, imported an estimated 1664 armoured vehicles during this period and took deliveries from the USA of transport and electronic reconnaissance aircraft, guided bombs and unmanned aerial vehicles (UAVs) for its operations in Afghanistan. Poland also received armoured vehicles and UAVs for use in Afghanistan.

- Azerbaijan ranked as the 40th largest importer of major conventional weapons in 2006-10. The volume of imports by Azerbaijan in 2006-10 was 323 per cent higher than in 2001-2005. Azerbaijan has imported a large quantity of tanks, armoured vehicles, aircraft and artillery during this period. It is currently seeking foreign assistance to develop its own arms industry. These acquisitions were made against a backdrop of increasingly bellicose rhetoric towards Armenia regarding the disputed region of Nagorno-Karabakh.

\section{The Middle East}

Middle Eastern states accounted for 17 per cent of international transfers of major conventional weapons in the period 2006-10, down from 21 per cent in 2001-2005. During 2006-10, 23 per cent of all major arms transfers to the Middle East went to the UAE, 14 per cent to Israel and 13 per cent to Egypt. In June 2010 the UN imposed an embargo on the supply of most major weapons to Iran.

- The UAE was the 6th largest arms importer worldwide in 2006-10. While its arms imports in 2010 were lower than in the previous years, the UAE will probably remain a top arms importer in the coming years based on a significant order backlog and plans for further major contracts for advanced weapons. The USA, France, Italy and Russia are the key suppliers to the UAE, and at least 10 other countries are supplying major arms to the country.

- In 2006-10 Egypt received 60 per cent of its imports of major arms from the USA, including M-1A1 tanks and M-113 armoured vehicles of the type present during demonstrations in the country in January 2011. Other suppliers included Russia ( 15 per cent), Montenegro ( 6 per cent), the Netherlands (6 per cent) and China (5 per cent). Russia's MiG-29 combat aircraft and the Chinese-Pakistani JF-17 have also been competing for an Egyptian order.

- Saudi Arabia ranked as the 22nd largest arms importer in 2006-10. However, deliveries are beginning on several major arms procurement programmes, including the import of 72 Typhoon combat aircraft from 
SIPRI is an independent international institute dedicated to research into conflict, armaments, arms control and disarmament. Established in 1966, SIPRI provides data, analysis and recommendations, based on open sources, to policymakers, researchers, media and the interested public.

\section{GOVERNING BOARD}

Göran Lennmarker, Chairman (Sweden)

Dr Dewi Fortuna Anwar (Indonesia)

Dr Vladimir Baranovsky (Russia)

Ambassador Lakhdar Brahimi (Algeria)

Jayantha Dhanapala

(Sri Lanka)

Susan Eisenhower

(United States)

Ambassador Wolfgang

Ischinger (Germany)

Professor Mary Kaldor

(United Kingdom)

The Director

\section{DIRECTOR}

Dr Bates Gill (United States) the UK, 724 LAV/Piranha armoured vehicles from Canada and 6 A-330 MRTT tanker aircraft from France. In 2010 it was announced that Saudi Arabia was negotiating several major deals, including procurement of $84 \mathrm{~F}-15 \mathrm{~S}$ combat aircraft and $70 \mathrm{AH}-64 \mathrm{D}$ combat helicopters from the USA, 40 more Typhoon combat aircraft from the $\mathrm{UK}$ and a range of other weapons which several countries are competing to supply.

- Israeli imports of major arms were on the decline in 2010 after the delivery of $102 \mathrm{~F}-16 \mathrm{I}$ combat aircraft, financed by the USA, was completed in 2009. However, US military aid to Israel continued, including an agreement signed in 2010 to supply Israel with a first batch of $20 \mathrm{~F}-35$ combat aircraft. Israel failed to agree to procure a submarine and two frigates from Germany, the only other significant supplier of major arms to Israel. Germany did not want to pay 33 per cent of the costs as it had done for a 2006 order for 2 Dolphin submarines, which Israel is to receive in 2011-12.

\section{ABOUT THE SIPRI ARMS TRANSFERS PROGRAMME}

The SIPRI Arms Transfers Programme is one of SIPRI's longest running research programmes. As well as maintaining the SIPRI Arms Transfers Database, the programme undertakes research to identify shifting trends in international arms transfers.

The SIPRI Arms Transfers Database, $<$ http://www.sipri.org/databases/ armstransfers $>$, is a fully searchable online database containing information on all international transfers of seven categories of major conventional weapons from 1950 to the most recent full calendar year. It can be used to generate detailed written reports and statistical data on these transfers, including the suppliers and recipients, the type and number of weapon systems ordered and delivered, the years of deliveries, and the financial value of the deal.

\section{sipiri}

STOCKHOLM INTERNATIONAL PEACE RESEARCH INSTITUTE

Signalistgatan 9

SE-169 70 Solna, Sweden

Telephone: +4686559700

Fax: +4686559733

Email: sipri@sipri.org

Internet: www.sipri.org 